індивідуальні особливості.

\title{
Література
}

1. Базова програмарозвитку дитини дошкільного віку «Я у Світі» / наук. кер. та заг. ред. О. Л. Кононко. - [3-те вид., випр.]. - К. : Світич, 2009. - 430 с. 2. Еманова 3. І. Музично-виконавська діяльність: сучасні підходи / 3. І. Еманова // Дошкільне виховання. - К. : Світич, 2009. - № 8.- С. 14-17. 3. Загадковий світ ємоцій. Розвиток емоційної сфери дошкільників / упоряд. І. В. Молодушкіна. - Х. : Вид. група «Основа», 2010. - 207 с. 4. Молчанова А. С. На вкус и цвет/ А. С. Молчанова. - М. : Искусство, 1966. - 200 с. 5. Нечай С. О. Дитина і звуки світу / С. О. Нечай // Дошкільне виховання.- К. : Світич, 2011. - № 7. - С. 17-20. 6. Театралізована діяльність дошкільників. Художньо-естетичний розвиток / упоряд. Л. А. Шик. - Х. : Вид. група «Основа», 2011. - 176 с.

УДК $378.147: 371.38$

Віктор Мадзігон

\section{КОМПЕТЕНТНІСНИЙ ПІДХІД У СИСТЕМІ НЕПЕРЕРВНОЇ ЕКОНОМІЧНОЇ ОСВІТИ}

Мадзігон В. В. Компетентнісний підхід у системі неперервної економічної освіти.

У статті досліджуються напрями вдосконалення парадигми розвитку національної економічної освіти в контексті інноваційного оновлення іiі змісту, обгрунтовуються теоретико-методичні засади формування професійних знань майбутніх фахівців економічного профілю в системі неперервної освіти як важливої передумови розбудови економіки знань.

Ключові слова:освіта, економічна освіта, парадигма, професійна компетентність, фахівці економічного профілю, система знань, інноваційна економіка, неперервна освіта, економіка знань.

Мадзигон В. В. Компетентностный подход в системе непрерывного экономического образования.

В статье исследуются направления усовершенствования парадигмы развития национального экономического образования в контексте инновационного обновления ее системы, обосновываются теоретико-методические основы формирования профессиональных знаний будущих специалистов экономического профиля в системе непрерывного образования как важное условие развития экономики знаний.

Ключевые слова:образование, экономическое образование, парадигма, профессиональная компетентность, специалисты экономического профиля, система знаний, инновационная экономика, непрерывное образование, экономика знаний.

Madsigon V. V. Competent approach to the Economic education system continuously.

The article examines the ways of improving the national economic development paradigm of education in the context of the renewal of its innovative system. The author justifies the theoretical and methodological basis for the formation of professional knowledge of future specialists in economics in the system of continuous education as an important condition for the development of the knowledge economy.

Key words:education, economic education, paradigm, professional competence, experts in economics, a system of knowledge, innovation economy, continuous education, knowledge economy. 
Нині актуалізується проблема розроблення концептуальних засад щодо підвищення економічної ефективності української освіти, де вагоме місце відведено питанням формування системи професійних знань майбутніх фахівців економічного профілю, у якій з урахуванням принципу наступності були б структуровані тематичні блоки теоретичної та реальної економіки, ефективно взаємодіяли підсистеми профільної, середньої і вищої професійно-економічної освіти, а пріоритетним був би проектно-творчий підхід до поетапного формування економіки знань в системі неперервної економічної освіти в умовах навчально-наукового комплексу: «школа коледж - університет» [2, с. 57].

Методологічні та наукові підходи, що уможливлюють розв'язання проблеми формування системи професійних знань у майбутніх фахівців економічного профілю, виховання культури економічних відносин і підготовки молоді до ринкової економіки обгрунтовані та сформульовані у працях 3 філософії освіти відомих вітчизняних науковців: В. Андрущенка, А. Павленко, О. Падалки, В. Мадзігона, А. Нісімчука, О. Шпака, М. Вачевського, Є. Савельєва, О. Аксьонової та багатьох інших.

Водночас у більшості науково-методичних праць дослідники не виокремлювали проектувально-творчий підхід до формування системи професійних знань у майбутніх фахівців економічного профілю, якими потенційно є старшокласники загальноосвітніх шкіл, приділили недостатньо уваги принципу наступності формування системи допрофесійних знань 3 економіки у профільній школі i професійних знань в економічних коледжах, тобто не ставили за мету досліджень теоретико-методичні підходи до формування професійних знань у системі неперервної освіти майбутніх фахівців економічного профілю. Водночас навчально-науковий комплекс типу «школа з їі економічним профілем - економічний коледж - економічний університет» $\epsilon$ сприятливим навчальним середовищем задля ефективного формування системи професійних знань у майбутніх фахівців з економіки, які володіють економічним профілем обдарованості і мають потребу в неперервній економічній освіті.

Виходячи $з$ вищезазначеного, необхідно визнати, що проектно-творчий підхід до формування економічних знань у майбутніх фахівців економічного профілю залишається недостатньо дослідженим. Відчутнішою стає відсутність дослідноінноваційного компонента професійної економічної підготовки фахівців, у якому були б враховані потреби розвитку природних здібностей кожного учня чи студента: освітні, культурні, проектувально-творчі. Лише творчо розвинутий фахівець здатний бути економічно ефективною особистістю на сучасному ринку праці. Саме сучасний ринок праці, його розвиток, а також динаміка змін на ньому вимагає від освітянських закладів підготовки фахівців 3 інноваційними знаннями та вміннями, які вільно володіють теоретичними основами економічних знань, знаються на всіх аспектах застосування в практичній діяльності інноваційних технологій, мають навички поновлення та вдосконалення знань упродовж життя [5, с. 265]. Отже, на часі $\epsilon$ необхідність подальшого вдосконалення наукового обгрунтування і впровадження інновацій, модернізації освітньої галузі загалом й економічної освіти зокрема.

Між теорією і практикою формування професійних знань у майбутніх фахівців економічного профілю склалися певні суперечності, які стосуються взаємодії внутрішнього особистісно-інформаційного середовища сучасних учнів та студентів і зовнішнього інформаційно-педагогічного середовища навчальних закладів економічної освіти. Такі суперечності є між:

- наявністю підсистеми допрофесійного формування економічних знань старшокласників у профільній загальноосвітній школі, підсистеми професійного 
навчання молодших спеціалістів економічного профілю у коледжах, підсистеми професійної підготовки майбутніх фахівців з економіки у вищих навчальних закладах i відсутністю теоретико-методичного обгрунтування наукових підходів до розроблення модернізованої системи формування професійних знань учнів і студентів у неперервній економічній освіті;

- суспільною потребою у фахівцях економічного профілю, здатних до проектнотворчої діяльності в умовах швидкозмінних технологій і недостатнім теоретичним обгрунтуванням проектувального підходу до формування системи професійних знань майбутніх фахівців економічного профілю;

- потребою фахівців економічного профілю у ключовій проектувальній компетентності і відсутністю науково обгрунтованої методичної системи в задоволенні такої потреби у вищих економічних навчальних закладах.

Розвиток економічної освіти зумовлюється новою ерою «економіки знань». Відтак в епоху нових суспільних і освітніх цінностей нагальною стає проблема формування «економічної людини», а також такі ключові поняття, як: дидактичний принцип економічної ефективності освіти; ключова економічна компетентність; економічна здібність і економічна обдарованість [3, с. 9].

Сучасна вітчизняна освіта потребує докорінної перебудови неперервної системи економічної освіти з урахуванням компетентнісного й особистісно зорієнтованого підходів. Прерогатива належить профільним школам, коледжам, університетам, які мають дати майбутнім фахівцям економічного профілю особистісно-ціннісні і сенситивно-доцільні знання 3 економічних теорій, зокрема, 3 мікроекономіки, підприємництва, бізнесу,фінансової системи, менеджменту i маркетингу інтелектуальної власності, інформації, професійні знання національної та світової економіки іглобальних процесів ринкової економіки [4, с. 41].

Автор вивчав праці, присвячені теоретичним засадам навчання старшокласників за економічним профілем у загальноосвітній школі. Було виявлено, що компетентнісному й особистісно зорієнтованому підходам до профільного економічного навчання приділено недостатньо уваги. У міжшкільних навчальновиробничих комбінатах також не виявлено досвіду роботи 3 економічно обдарованими старшокласниками загальноосвітніх шкіл.

Педагогічне i психологічне діагностування економічно обдарованих старшокласників, його зміст i структурні особливості, наукове обгрунтування, формулювання сутності залишилися поза межами уваги вітчизняних дослідників психолого-педагогічної науки, незважаючи на вимоги особистісно і компетентнісно зорієнтованої доктрини української освіти, урядових програм щодо виявлення i педагогічної підтримки обдарованої молоді, стандартів базової і повної середньої освіти.

Особливо різнобічними є дослідження проблеми формування професійних знань у вищих економічних навчальних закладах. Під час аналізу сучасних теоретичних джерел $з$ економіки на засадах людиноцентричного підходу виявлено розбіжність між науковими положеннями 3 філософії освіти, вимогами особистісно і компетентнісно зорієнтованої доктрини української освіти i реальним станом формування професійних знань у неперервній системі економічної освіти. Так, сутність компетентності полягає у професійному володінні не лише знаннями, уміннями й навичками, але й у позитивному ставленні фахівця до їх здобуття i використання [1, с. 72]. Тобто компетентісний підхід нерозривно пов'язаний 3 особистісно зорієнтованим, а відтак і здатністю учнів та студентів до самоосвіти на 
всіх іiі рівнях: профільному, середньому, вищому. До самоосвіти, саморозвитку і культурної самореалізації, до навчання в неперервній системі економічної освіти i навчання впродовж життя переважно здатні економічно обдаровані учні і студенти.

Економічно обдарований - це компетентний фахівець, здатний до оволодівання професійними знаннями 3 економіки 3 мінімальними затратами сутнісних сил $\mathrm{i}$ максимальними навчальними досягненнями у процесі неперервної економічної освіти. Економічно обдаровані учні профільної школи, економічних коледжів і студенти вищих економічних навчальних закладів відзначаються сформованістю підприємницької компетентності, передбаченої новими стандартами освіти. Вимогою стандартів є розширення меж знань 3 урахуванням інноваційних та глобальних змін. На такій методичній засаді освітнього нормативного документа стає можливою модернізація формування системи професійних знань у майбутніх фахівців економічного профілю, які виявляють природну економічну обдарованість і потребують підтримки задля iіi подальшого розвитку в педагогічно доцільному навчальному середовищі. Таким педагогічно доцільним навчальним середовищем і може бути навчально-науковий комплекс типу «школа-коледж-університет» економічного профілю.

Ринкова економіка запроваджує нові умови організації процесу навчання в освітніх навчальних закладах щодо формування високих фахових знань у майбутніх фахівців економічного профілю. Репродуктивний метод навчання не задовольняє сьогодення. Суспільству необхідні фахівці з творчим мисленням, умінням орієнтуватися в конкурентному ринковому середовищі. Фундамент економічної освіти і розвитку творчих здібностей дає загальноосвітня школа, яка, крім загальноосвітніх знань, покликана здійснювати економічне виховання учнівської молоді, здійснювати у процесі навчання молоді набір відповідних функцій, які спонукають особистість до вибору професії й орієнтації у трудовій діяльності в умовах ринкової системи. Сенситивно доцільним змістовим компонентом професійних знань старшокласників профільної школи є основи економічної теорії господарювання, підприємництва, побудова та функціонування ринкової інфраструктури.

Для ознайомлення старшокласників із фінансовою системою ринкової економіки ефективним виявився проектно-технологічний підхід - здатність учнів застосовувати знання, уміння й особистий досвід у навчальній пошуковій діяльності. Його сутність полягала в розробленні учнями профільної школи різноманітних фінансових проектів (бізнес-планів), які стосувалися таких сфер життєдіяльності: людина-природа, людина-техніка, людина-людина, людина - художні образи, людина-знакові системи. Проектування передбачено у змістовому наповненні стандарту освітньої галузі «Технології, у профільній програмі з основ економіки, затвердженій МОН України. Учні мають змогу обрати особистісно значуще середовище для розроблення навчального майстер-плану, бізнес-плану.

Отже, розглянувши питання сучасного розвитку формування ефективної системи неперервної економічної освіти впродовж життя, переходу національної економіки, заснованої на виробництві нових знань, використання досвіду розвинених країн щодо підготовки та перепідготовки кадрів для системи економічної освіти, а також позитивні можливості інноваційного потенціалу економічної освіти, можемо зробити низку взаємопов' язаних висновків.

По-перше, необхідно уточнити сутність понять «модернізація системи професійних знань 3 економіки», «майбутні фахівці економічного профілю».На нашу думку, модернізація системи професійних знань з економіки полягає в удосконаленні 
змісту навчання учнів профільної школи професійних знань 3 основ економічної теорії, молодших спеціалістів економічних коледжів - професійних знань з основ виробничої діяльності підприємств, студентів вищих економічних навчальних закладівпрофесійних знань 3 міжнародних економічних відносин у світовому господарстві. Результатом модернізації $є$ ієрархічна система професійних знань 3 економіки, яка поетапно оволодівається учнями та студентами у сприятливих педагогічних умовах навчально-наукового комплексу: профільна школа - коледж - університет.

Майбутні фахівці економічного профілю - це старшокласники загальноосвітньої школи, яким притаманна ключова компетентність підприємницької діяльності як пріоритетна; молодші спеціалісти економічних коледжів, які характеризуються проектно-творчим підходом до здобуття професійних знань 3 економіки, студенти вищих економічних навчальних закладів, знання яких виявляється в креативності й пошуках інноваційних професійних знань з економіки.

По-друге, запропонувати способи модернізації профільного вивчення економіки у загальноосвітній школі, з-поміж яких педагогічно доцільною є методична система, пріоритетними компонентами якої $\epsilon$ проектно-творчі способи оволодівання допрофесійними знаннями 3 економіки і формування ключової компетентності підприємницької діяльності старшокласників.

По-третє, існує нагальна необхідність удосконалення теоретико-методичних засад особистісно і компетентнісно зорієнтованої професійної економічної освіти молодших спеціалістів у коледжах. В економіці, яка базується на знаннях, основним ресурсом розвитку постає інноваційний потенціал країни, залучений до регіонального ринку праці, до малого і середнього бізнесу. Тому педагогічна система професійної економічної освіти молодших спеціалістів є головними джерелом інноваційної моделі розвитку економіки з урахуванням iї регіональних особливостей.

По-четверте, необхідно актуалізувати інноваційну теорію й методику формування професійних знань майбутніх фахівців з економіки у вищих навчальних закладах для того, щоб захистити економічний суверенітет України, основними складниками якого $\epsilon$ розвиток продуктивних сил, інвестиційно-інноваційних відносин, економічної власності і господарського механізму. Задля цього важливо покращувати сприятливі педагогічні умови для навчання в магістратурі студентів, які мають стати фахівцями 3 високим творчим, інтелектуальним, організаторським потенціалом, що запобігатиме зниженню інтелекту нації, сприятиме зміцненню кадрового потенціалу у вітчизняній економіці.

Урахування викладеного вище і подальше послідовне впровадження в освітню галузь прискорить розбудову в Україні інноваційної освітньої політики, вибудовування економіки знань в системі неперервної освіти.

\section{Література}

1. Вачевський М. В. Основи економіки: [навч. посібник] / М. В. Вачевський, В. М. Мадзігон та інші. - К. : Педагогічна думка, 2007. - 612 с. 2. Кулішов В. В. Методичні засади формування економічної компетентності у процесі підготовки фахівців технологій: [монографія] / В. В. Кулішов. - К. : Каравела, 2011. - 567 с. 3. Кулішов В. В. Теоретичні і методичні засади формування системи професійних знань майбутніх фахівців економічного профілю: автореф. дис. на здобуття наук. ступеня докт. пед. наук: 13.00 .04 / В. В. Кулішов. - К., 2012. - 41 с. 4. Падалка О. С. Економіка освіти та управління: [навч. посібник] / О.С. Падалка. - К. : Педагогічна думка, 2012. - 184 с. 5. Смілянець О. Г. Інноваційні педагогічні технології в післядипломній освіті фахівців економічної кібернетики / О. Г. Смілянець // Сучасні 
інноваційні технології та інноваційні методики навчання у підготовці фахівців: методологія, теорія, досвід, проблеми: зб. наук. праць. - Вінниця : Вінницький державний педагогічний університет імені Михайла Коцюбинського, 2010.Вип. 25. - С. 265-272.

\section{ЛІНГВОДИДАКТИЧНИЙ ПОТЕНЦІАЛМІЖКУЛЬТУРНОГО СПІЛКУВАННЯ ЯК КАТЕГОРІЯ МЕТОДИКИ НАВЧАННЯ ІНОЗЕМНИХ МОВ}

Махінов В. М. Лінгводидактичний потенціал міжкультурного спілкування як категорія методики навчання іноземних мов.

У статті розглядаються теоретичні засади міжкультурного спілкування як категорії методики навчання іноземних мов та їх лінгводидактичний потенціал, теоретично обгрунтовано нову міжкультурну лінгводидактичну парадигму, в основу якої покладено концепт формування мовної особистості, що відкриває широкі можливості пошуку нових оптимальних шляхів удосконалення іншомовної освіти студентів.

Ключові слова:теоретичні засади міжкультурного спілкування, методика навчання іноземних мов, мовна особистість, мовленнєва діяльність, іншомовна освіта.

Махинов В. Н. Лингводидактический потенциал межкультурного общения как категория методики обучения иностранным языкам.

В статье рассматриваются теоретические основы межкультурного общения как категории методики обучения иностранным языкам и их лингводидактический потенциал,теоретически обоснована новая межкультурная лингводидактическая парадигма, в основу которой положен концепт формирования языковой личности, что открывает широкие возможности поиска новых оптимальных путей совершенствования иноязычной образования студентов.

Ключевые слова:теоретические основы межкультурного общения, методика обучения иностранных языков, языковая личность, речевая деятельность, иноязычное образование.

Machinov V. N. Lingvodidactical potential of intercultural communication as a category of methods of teaching foreign languages.

The article examines theoretical basics of intercultural communication as a category of methods of foreign language teaching and their linguistic and didactic potential, substantiated the new intercultural paradigm, which is based on the concept of forming the language personality, which opens up opportunities to search for new optimal ways of improving foreign language education students.

Key words:theoretical fundamentals of intercultural communication, methodology of teaching of foreign languages, linguistic personality, speech activity, foreign language education.

Головним завданням лінгводидактики як загальної теорії навчання іноземної мови є розроблення методології навчання мови, аналіз застосовуваних дослідницьких підходів, прийомів, принципів і концепцій. Наукова цінність лінгводидактичної теорії, як найвищої форми організації наукового знання, вимірюється обсягом емпіричних фактів, які складають предмет іiі вивчення. Вона охоплює сфери систематизації, 